\title{
CHARACTERISTICS OF DUWET KARST SPRING BASED ON BASEFLOW INDEX ASSESSMENT AND ITS POTENTIAL IN FRESH WATER SUPPLY
}

\author{
Pipit Wijayanti ${ }^{1}$, Rita Noviani ${ }^{2}$ \\ ${ }^{1,2}$ Geography Education, Faculty of Teacher Training and Education, \\ Universitas Sebelas Maret \\ Email: pipitwijayanti@staff.uns.ac.id
}

\begin{abstract}
This study aims to determine the potential of Duwet springs and their availability for supplying fresh water to the surrounding community. we use hydrographs to analyze aquifer characteristics. To analyze the hydrographs, we use water level and spring discharge data. Automatic Water Level Record (AWLR) records water level data for 1 dry season and 1 rainy season every 15 minutes. We use the volumetric method to measure the spring discharge 14 times. We compare the base flow and demand over a year to analyze the potential for fresh water. The results show that the Stage discharge rating curve $y=0.0002 e 5,453 x$ with $R^{2}$ value of 0.87. Duwet Springs is a perennial spring that has a small discharge (class VI). The largest discharge ever recorded was $0.69 \mathrm{~L} / \mathrm{s}$ (March 7, 2020) and the smallest recorded was $0.12 \mathrm{~L} / \mathrm{s}$ (August 21, 2020). BFI value varied between 0.05 and 1 with mean 0.801. The total base flow is 2490675.734 L (rainy season) and 1563419.873 L (dry season). These springs are sufficient for $75 \%$ of the rainy season and $84 \%$ in the dry season. This indicates that the existence of Duwet springs is very important for the surrounding community.
\end{abstract}

Keywords: Karst Spring; Base Flow Index; Fresh water

\section{A. INTRODUCTION}

Karst aquifers have a unique drainage system due to high dissolution which results the secondary porosity develops intensively. This phenomenon makes the karst area have intensive zoning system (Bakalowicz, 2005; Ford \& Williams, 2007; Jennings, 1971; Sweeting, 1972). It causes the surface underground hydrological system to develop more intensively than the surface flow system (Adji \& Haryono, 2017). Therefore, dissolving is a very important part of the development of karst (karstification), compared to its relatively small role in other landforms (Ford \& Williams, 2007; Gillieson, 2011; Palmer, 1999).

The intensive development of underground hydrology causes karst areas have high potential for storing water, indicated by the high water supply in the karst area which is used to fulfill the needs of fresh water. Carbonate rock aquifers in the world are able to supply $25 \%$ of the world's water needs, while their distribution is relatively small, around 12 - 15.2\% (Andreo et al., 2010; Ford \& Williams, 2007; Goldscheider et 
al., 2020). Recent studies show that 678 million or $9.2 \%$ of the entire world population depends on water in the karst (Stevanović, 2019).

However, this potential water lies underground, which the depth depends on the thickness of the carbonate rock, making it difficult to gain to fulfill daily needs of water in community. This lithological condition causes karst areas to be identical with drought. In fact, on the meteorological side, karst areas that develop in the tropical places have high availability with a 7-8 month surplus (Wijayanti et al., 2015).

This condition makes springs become sources of fresh water for people in karst areas that are easily accessible because it doesn't require high technology to explore it. People can use gravity force to distribute the water. The characteristic of karst springs is more controlled by the level of karst development (Adji \& Haryono, 2004) that the existence is influenced by rainfall, topography, geological structure, permeability, and aquifer characteristics (Sudarmadji et al., 2012). Characteristics of karst aquifers are usually difficult to determine. Therefore, a hydrograph approach to rainfall response is important (Bonacci, 2009; Gunn, 1985; Manga, 1999; Padilla et al., 1994; Waltham et al., 1983; William B. White, 2002).
Given the importance of springs for communities in karst areas, the core research aims to determine the characteristics of springs, especially their ability to supply fresh water. The ability to supply fresh water is carried out by analyzing the amount of base flow available during the dry season. This is important as it's used for the management and conservation of springs in karst areas. The study was conducted at Duwet springs which is located in Duwet Hamlet, Gendaran Village, Donorojo District, Pacitan Regency, East Java, ( $8^{\circ} 05^{\prime} 38,95^{\prime \prime} \mathrm{S} \& 110^{\circ} 57^{\prime} 27.88$ "E). This spring is situated at the eastern part of Gunungsewu Karst.

\section{B. MATERIALS AND METHODS}

The research area is situated in some part of the Gunungsewu Karst which is located in the east (Figure 1). Administratively, it is located in Pacitan Regency, East Java, which is included in the Wonosari-Punung Formation. The Wonosari-Punung Formation consists of massive coral reef limestones in the south and layered limestones in the north (Balazs, 1971; Bemmelen, 1949; Surono et al., 1992; Waltham et al., 1983).

The type of soil in the study area is dominated by the lithosol mediteran and rensina complex which covers more than $90 \%$ of the total study area. The land use 
that dominates the study area is crop field with a percentage of more than $50 \%$ and is followed by settlements and rainfed rice fields (Wijayanti et al., 2015). This condition is understandable given the topographical of the area which is hilly with moderate to steep slopes that limits the land use as a built-up area.

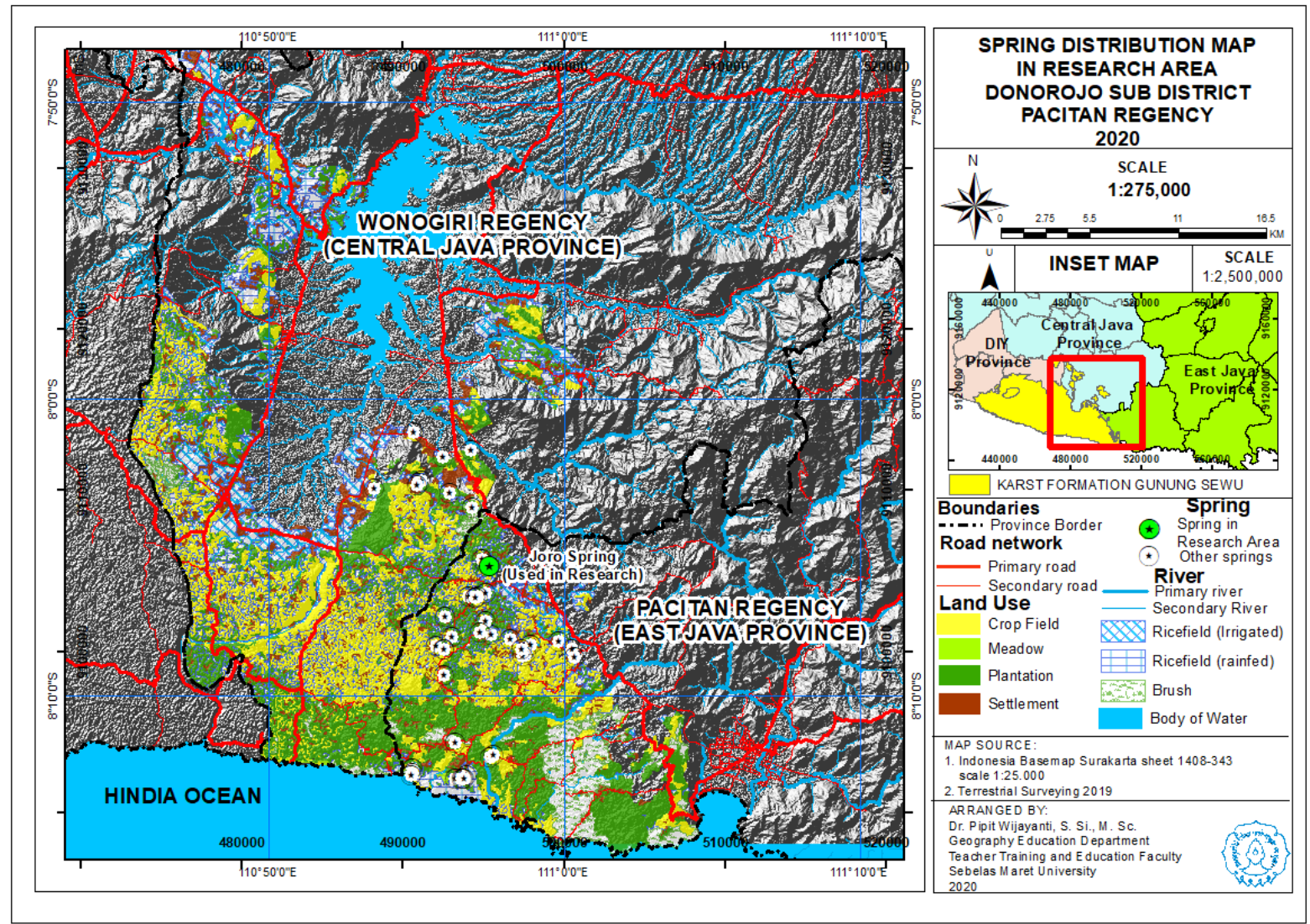

Figure 1. Research area which contains the Distribution of Springs and the Land Use

The aquifer characteristics were analyzed using flow hydrographs. To analyze the flow hydrographs, we use water level and spring discharge data. The water level is obtained by using two Automatic Water Logger Recorded (AWLR) devices that are mounted on springs and open air (barometric). The spring AWLR is used to record the water level, while the barometric AWLR is used to record the barometric pressure that occurs in the air. The result of combining the two tools is used for obtaining a smother hydrograph. Recording of water level is carried out for 1 dry season period and 1 rainy season period, with recording phase every 15 minutes.

Discharge data is measured by the volumetric method. Discharge measurements were carried out 14 times during the study period, representing the 
rainy and dry seasons. The warped flow curve is obtained by calculating the regression between water level and discharge. Water level in regression measurement is obtained by looking at the AWLR results recorded at the same time as the direct discharge measurement. Furthermore, the regression results are used to obtain the discharge data based on water level during the recording period. The relationship between discharge and water level is described by the formula:

Q Q e $-\alpha=0$

Where Qt is the reliable discharge in one time, Q0 is the discharge at the beginning of the recession $(\mathrm{m} 3 / \mathrm{s}), \alpha$ is the recession coefficient and it is the time elapsed between Qt and Q0. While the recession constant is the result of the exponential number (e) the power of the recession coefficient $(\alpha)$.

The baseflow separation introduced automatic technique for hydrograph separation using digital filtering method. Separation of total discharge into two components, baseflow and direct runoff performed using recursive digital filtering as expressed in Eq.1. BFI Index is measured using formula:

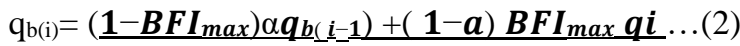

$$
\text { 1-aBFI } \max
$$

qbi $[\mathrm{L} 3 / \mathrm{T}]$ is the baseflow at time step $\mathrm{t}[\mathrm{T}]$, a [dimensionless] is the filter parameter and Qt $[\mathrm{L} 3 / \mathrm{T}]$ is the streamflow at time step t. Since BFI max cannot be identified prior to separation, (Eckhardt, 2005) suggests using a value of 0.80 for perennial flow with porous aquifers, 0.50 for transient flow with porous aquifers, and 0.25 for perennial flow with hard rock aquifers. The use of BFImax $=0.50$ shows a filter equivalent to that proposed by (Chapman, 1991). (Chapman, 1991) formulation, filters are developed to prevent constant base flow in the absence of direct flow (similar to the filters of (Lyne \& Hollick, 1979; Nathan \& McMahon, 1990). The separation of the base flow is used to determine the potential of spring water to fulfill fresh water needs.

Potential of fresh water is obtained by comparing the volume of base flow for a year and the demand for fresh water. The need for fresh water is determined to be 66.37 liters / person / day in the dry season and 102.68 liters / person / day in the rainy season (Syahidin, 2016). This statement is based on research in karst areas with almost the same characteristics. 


\section{RESULTS AND DISCUSSION}

\section{Spring discharge}

Discharge rate measurements were carried out using the volumetric method. It was measured 14 times both during the rainy and dry seasons. Table 1 shows the results of the measurement of discharge and water level (TMA) recorded in the AWLR logger data. Based on the table, it can be seen that the highest discharge was $0.46 \mathrm{~L} / \mathrm{s}$ with TMA $1.055 \mathrm{~m}$ which occurred in March. While the smallest discharge is $0.021 \mathrm{~L} / \mathrm{s}$ with TMA 0.740 $m$ which occurs in September. Seasonally, there is fluctuation between the rainy season and the dry season in response to rain. The measurement results are then used to create a stage discharge rating curve.

Table 1. Discharge data measured in the field using the volumetric method

\begin{tabular}{ccccc}
\hline No & Date & Time & $\begin{array}{c}\text { Water level } \\
(\mathbf{m})\end{array}$ & $\begin{array}{c}\text { Discharge } \\
(\mathbf{l} / \mathbf{s})\end{array}$ \\
\hline 1 & $20 / 12 / 2019$ & $14: 45$ & 1,004 & 0,097 \\
\hline 2 & $19 / 01 / 2020$ & $14: 15$ & 1,007 & 0,098 \\
\hline 3 & $23 / 02 / 2020$ & $13: 15$ & 1,104 & 0,172 \\
\hline 4 & $22 / 03 / 2020$ & $15: 30$ & 1,065 & 0,232 \\
\hline 5 & $19 / 04 / 2020$ & $14: 30$ & 1,055 & 0,460 \\
\hline 6 & $09 / 07 / 2020$ & $11: 00$ & 0,769 & 0,025 \\
\hline 7 & $08 / 08 / 2020$ & $13: 30$ & 0,754 & 0,023 \\
\hline 8 & $15 / 08 / 2020$ & $14: 45$ & 0,758 & 0,024 \\
\hline 9 & $21 / 08 / 2020$ & $14: 15$ & 0,756 & 0,023 \\
\hline 10 & $30 / 08 / 2020$ & $13: 45$ & 1,024 & 0,092 \\
\hline 11 & $06 / 09 / 2020$ & $09: 30$ & 0,740 & 0,021 \\
\hline 12 & $13 / 09 / 2020$ & $11: 30$ & 0,754 & 0,023 \\
\hline 13 & $27 / 09 / 2020$ & $14: 45$ & 1,022 & 0,089 \\
\hline 14 & $02 / 11 / 2020$ & $15: 00$ & 1,028 & 0,097 \\
\hline
\end{tabular}

The stage discharge rating curve is a curve that describes the relationship between discharge and water level of springs. It is expressed by an exponential equation. Based on direct measurement discharge data and water level, the curve exponential equation is $\mathrm{y}=0.0002 \mathrm{e}^{5,453 \mathrm{x}}$; where $\mathrm{y}$ axis is the discharge and $\mathrm{x}$ axis is the water level (TMA) with an $\mathrm{R}^{2}$ value of 0.87 (Figure 2). The value of 
0.87 indicates that the water level determine $87 \%$ on the discharge. This value is sufficient to use the exponential regression equation as the basis for determining the discharge according to the water level data recorded every 15 minutes. An exponential regression between the water level and the discharge was carried out to be used as the basis for making hydrograph models of flow that occurred in the study area.

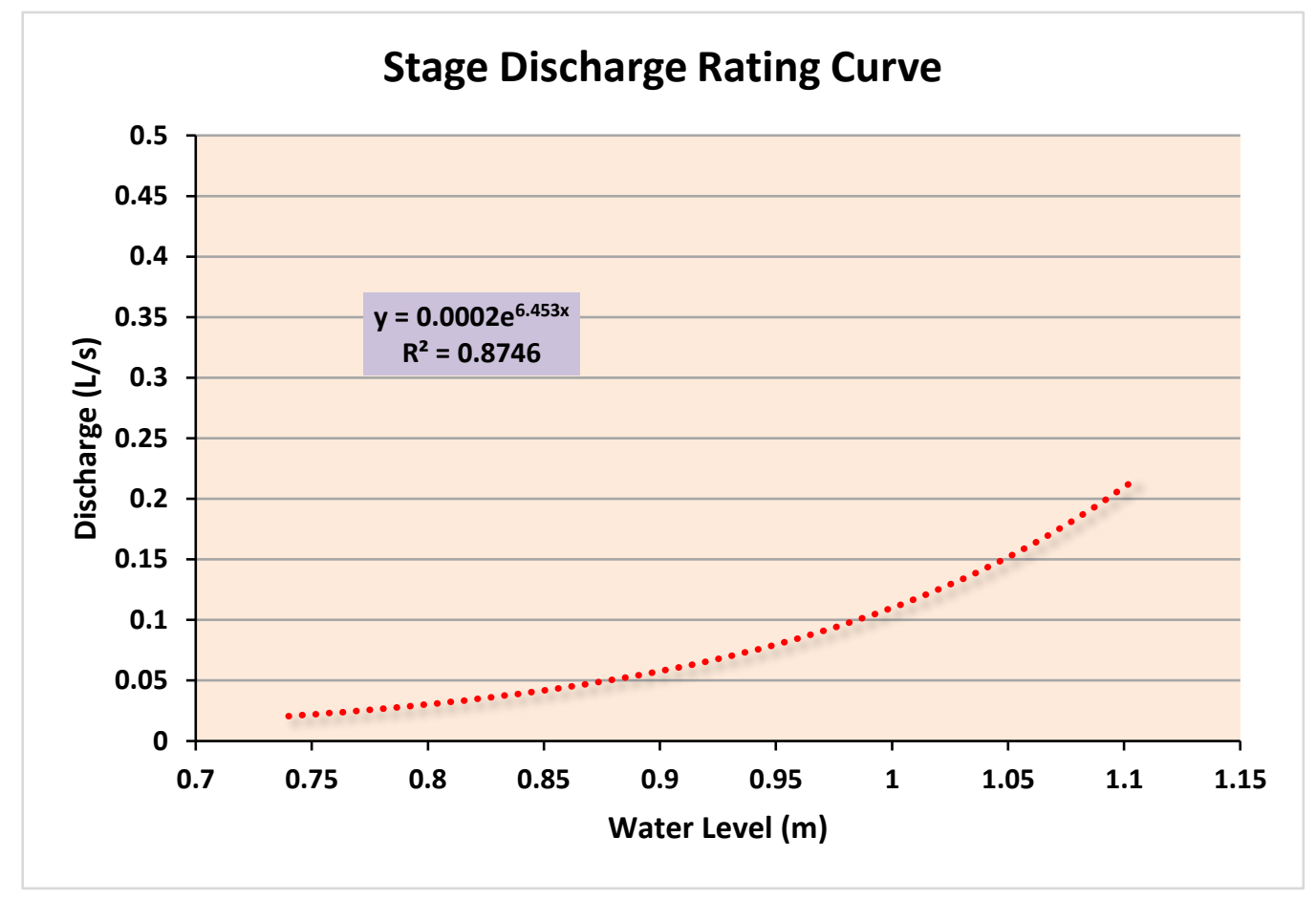

Figure 2. Stage discharge rating curve Duwet springs

\section{Hydrograph}

Flow hydrograph is the relationship between discharge and time. The Duwet springs flow hydrograph is presented in Figure 3. Based on this figure, it can be seen that the incoming rain will be responded by increasing flow rate. The highest flow rate occurs in March because it has the highest rainfall. Based on the relationship between the discharge taken in the field and the recording of the water level, The Duwet Springs discharge fluctuation varies according to the season. Duwet springs has small discharge fluctuations in the rainy season which is influenced by the amount of rainfall.

Therefore, during the dry season the spring has small discharge fluctuations. This is caused by the 
supply of water from rain that occurs only during the rainy season, while in the dry season there is no supply from rain, so the existing flow is the basic flow of the Duwet Springs. The average debit of Duwet springs was $0.161 \mathrm{~L} / \mathrm{s}$, which according to Meinzer it is categorized as class 6 spring. The largest debit was 0.69 L/s which occurred on March 7, 2020. Meanwhile, the smallest debit was 0.12 L/s which occurred on 21 August 2020 (last measurement in the field). This shows that the Duwet springs are located within the epikarst, where the fluctuation of discharge is small and the discharge flows throughout the year. After May, the discharge tends to fall continuously, due to the absence of rain at the research location so that the flows is the bottom flow from the Duwet springs.

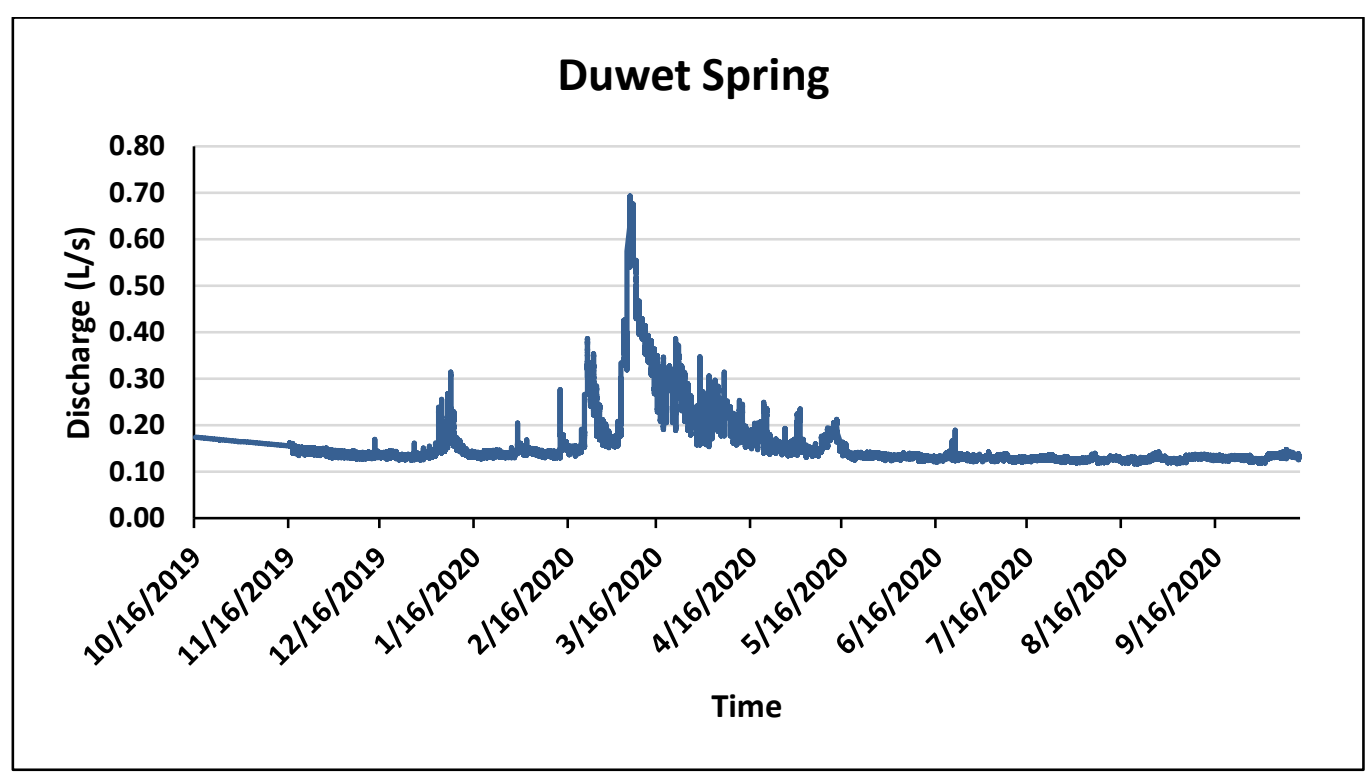

Figure 3. Flow hydrograph of Duwet springs

\section{Baseflow Analysis and Baseflow Index}

The base flow is the flow rate in a river that is still flowing during the dry season which comes from groundwater deposits in an aquifer (Fetter, 1994). The recession coefficient in this study was 0.994. This value is used to calculate the base flow index (BFI) at Duwet Springs.
The maximum BFI is determined at 0.801. This is based on the characteristics of the research area that has perennial flow with porous rock properties (karst) in accordance with the criteria in determining BFI using the (Eckhardt, 2005) model.

The results of the calculation shows that the BFI in the study locations 
varies between 0.05 and 1 with a mean value of 0.801 . The temporal flow distribution is shown in Figure 4. The high base flow index indicates that Duwet springs have a diffuse to fissure flow. Diffuse flow is a diffuse flow component added by infiltration water stored in karst hills and is laminar (Haryono, 2001; W B White, 1993). The average discharge is $0.128698 \mathrm{~L} / \mathrm{s}$ with a maximum discharge of $0.5 \mathrm{~L} / \mathrm{s}$ and a minimum discharge of $0.01 \mathrm{~L} / \mathrm{s}$. This indicates that $80.1 \%$ of the discharge in Duwet springs is the base flow. This basic flow is the potential for springs to fulfill fresh water needs. Temporally, there are variations caused by mucin. The total base flow during the rainy season is $2,490,675.734 \mathrm{~L}$ and the dry season is $1,563,419.873 \mathrm{~L}$

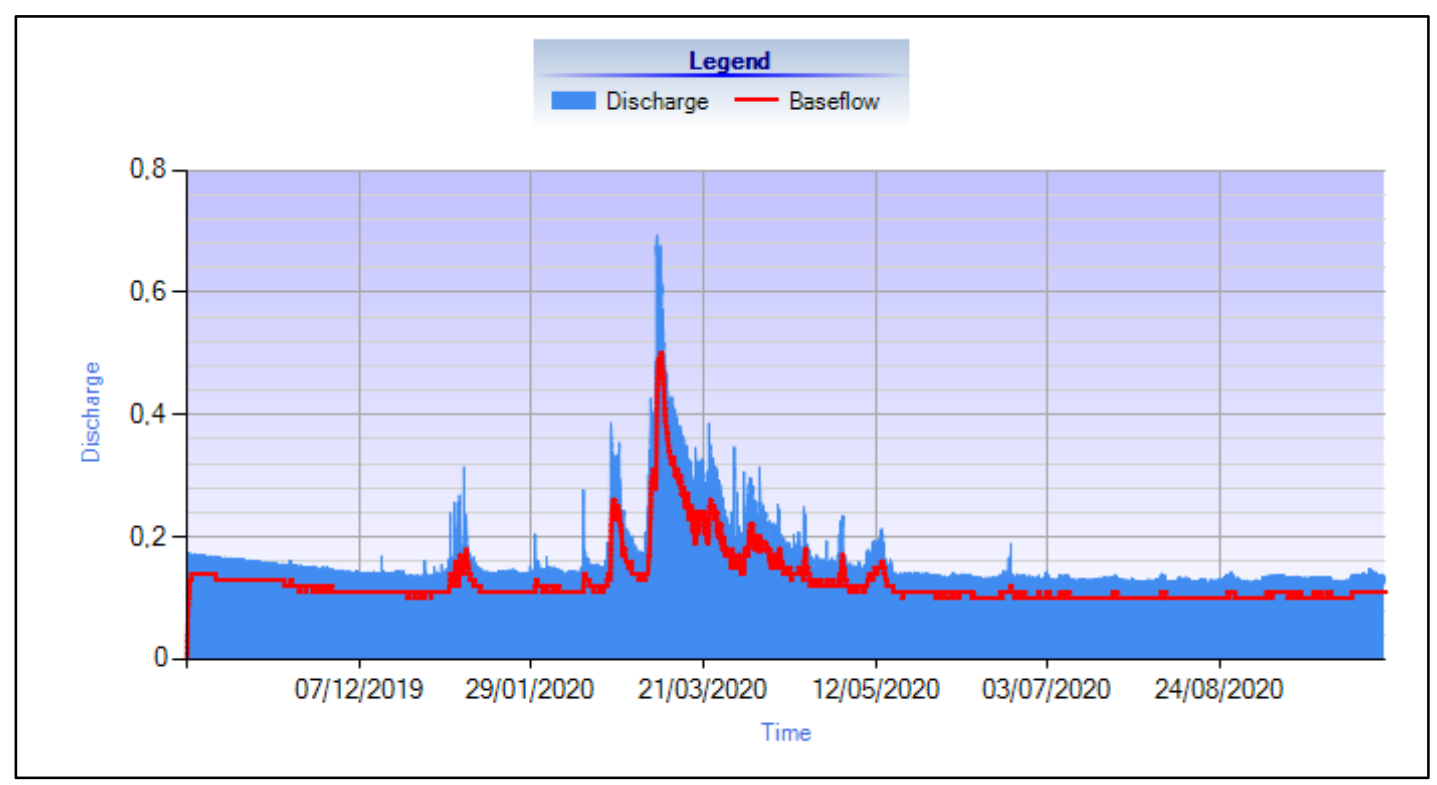

Figure 4. Base Flow Distribution graph of Duwet springs

\section{Duwet springs avaibility as fresh} water source

Based on the separation of the base flow at Duwet springs, it can be seen that there are 4,058,604.607 Liters/year amount of water which can be used to fulfill the needs of fresh water. This value is distributed into the rainy season and dry season, with different accumulated discharge. In the rainy season, Duwet springs is able to produce a base flow of $2,490,675.734 \mathrm{~L} / \mathrm{s}$, while in the dry season this ability decreases to $1,563,419.873 \mathrm{~L} / \mathrm{s}$. This cannot be separated from the influence of the rain that falls around Duwet springs. 
The need for water during the rainy season is $20,125.28 \mathrm{~L} / \mathrm{s}$, while in the dry season it is $11,282.9 \mathrm{~L} / \mathrm{s}$. These needs are based on the needs of people per day between the rainy and dry seasons. In the dry season the need for fresh water decreases, as this is a form of strategy and community adaptation to reduce fresh water consumption, considering that the research areas often experiencing drought. This means that the community performs a priority scale in meeting the need for fresh water. Based on this, it is possible to determine the ability of Duwet springs to supply fresh water needs. During the rainy season, this spring is able to supply fresh water to 124 people, while in the dry season it is able to supply 139 people (Table 2). Water consumption needs exculding for crops and livestock.
In fact, so far almost all residents of Duwet Hamlet have used springs to meet their needs for fresh water (51 out of 54 households). The amount per household consists of 3-4 family members. At least each family member has 3 members, so the number of people who depend on Duwet's springs is 165 persons. By looking at the availability and demand of the community, there is a shortage of fresh water supply both during the rainy and dry seasons. Even though it is not sufficient to meet the needs of fresh water, this spring is already sufficient for 75 percent of the rainy season and 84 percent in the dry season. This indicates that the existence of Duwet springs is very important for the surrounding community. It can be concluded that management is needed so the spring can be maintained and sustainable.

Table 2. Spring capability for supplying fresh water

\begin{tabular}{llcc}
\hline No & \multicolumn{1}{c}{ Parameter } & \multicolumn{2}{c}{ Season } \\
\cline { 3 - 4 } & & 1,478 & Dry \\
\hline 2 & Debit (L/s) & $2,490,675.734$ & $1,563,419.873$ \\
\hline 3 & Debit (L/season) & $\begin{array}{l}\text { Fresh water consumtion } \\
\text { (L/person/day) }\end{array}$ & 102.68 \\
\hline 4 & $\begin{array}{l}\text { Fresh water consumtion } \\
\text { (person/season) }\end{array}$ & $20,125.28$ & $11,282.9$ \\
\hline 5 & $\begin{array}{l}\text { Supplying capability } \\
\text { (person) }\end{array}$ & 124 & 139 \\
\hline 6 & Residents (persons) & 165 & 165 \\
\hline
\end{tabular}




\section{CONCLUSIONS}

Duwet spring is a perennial spring that has a small discharge, which is included in class VI. The largest discharge was $0.69 \mathrm{~L} / \mathrm{s}$ which occurred on March 7, 2020. Meanwhile, the smallest debit was $0.12 \mathrm{~L} / \mathrm{s}$ which occurred on August 21, 2020. The calculation results show that the BFI in the study location varies between 0.05 . and 1 with a mean value of 0.801 . The total base flow during the rainy season is 2,490,675.734 liters and the dry season is $1,563,419.873$ liters. These springs are able to fulfill 75 percent of fresh water needs in the rainy season and $84 \%$ in the dry season. This indicates that the existence of Duwet springs is very important for the surrounding community, so that management is needed so that this spring can be maintained and sustainable.

\section{E. ACKNOWLEDGMENTS}

Thanks to LPPM of Sebelas Maret University for funding this Fundamental Research Skim under contract of 1015/UN27/HK/2020.

\section{F. REFERENCES}

Adji, T. N., \& Haryono, E. (2004). Geomorfologi dan Hidrologi Karst.
Adji, T. N., \& Haryono, E. (2017). Konflik Antara Pemanfaatan Batugamping Dan Konservasi Sumberdaya Air Das Bribin Di Wilayah Karst Gunung Sewu. Makalah Lokakarya Nasional Menuju Pengelolaan Sumberdaya Wilayah Berbasis Ekosistem Untuk Mereduksi Konflik Antar Daerah.

https://doi.org/10.31219/osf.io/ut sXz

Andreo, B., Carrasco, F., Duran, J. J., \& LaMoreaux, J. W. (2010). Advances in Research in Karts Media. In Environmental Earth Sciences. https://doi.org/10.1007/978-3642-12486-0_61

Bakalowicz, M. (2005). Karst groundwater: A challenge for new resources. Hydrogeology Journal, 13(1), 148-160. https://doi.org/10.1007/s10040004-0402-9

Balazs, D. (1971). Intensity of The Tropical Karst Based on Cases of Indonesia. Budapest, 33-67.

Bemmelen, V. (1949). The Geology of Indonesia. The Haque.

Bonacci, O. (2009). Karst springs hydrographs as indicators of karst aquifers. Hydrological Sciences Journal, 38(1), 51-62. https://doi.org/10.1080/02626669 309492639

Chapman, T. G. (1991). Comment on "Evaluation of automated techniques for base flow and recession analyses" by R. J. Nathan and T. A. McMahon. Water Resources Research, 27(7), 1783-1784. https://doi.org/10.1029/91WR01 007

Eckhardt, K. (2005). How to construct recursive digital filters for 
baseflow separation.

Hydrological Processes, 19(2), 507-515.

https://doi.org/10.1002/hyp.5675

Fetter, C. W. (1994). Applied Hydrogeology. Waveland Press.

Ford, D., \& Williams, P. (2007). Karst Hydrogeology and Geomorphology. Wiley \& Sons.

Gillieson, D. S. (2011). Management of Caves. In Karst Management (Issue June 2011, pp. 141-158). Spinger. https://doi.org/10.1007/978-94007-1207-2

Goldscheider, N., Chen, Z., Auler, A. S., Bakalowicz, M., Broda, S., Drew, D., Hartmann, J., Jiang, G., Moosdorf, N., Stevanovic, Z., \& Veni, G. (2020). Global distribution of carbonate rocks and karst water resources. Hydrogeology Journal, 28(5), 1661-1677.

https://doi.org/10.1007/s10040020-02139-5

Gunn, J. (1985). A conceptual model for conduit flow dominated karst aquifers. In: "Karst Water Resources." Proc. Ankara Symposium, 587-596.

Haryono, E. (2001). Nilai Hidrologis Bukit Karst. Seminar EkoHidrolik.

Jennings. (1971).

Karst Geomorphology.

Brasil Blackwell Inc.

Lyne, V., \& Hollick, M. (1979). Stochastic Time-Variable Rainfall-Runoff Modelling. Institute of Engineers Australia National Conference, 89-93.

Manga, M. (1999). On the timescales characterizing groundwater discharge at springs. Journal of Hydrology, 219, 56-69.
https://doi.org/10.1016/S00221694(99)00044-X

Nathan, R. J., \& McMahon, T. A. (1990). Evaluation of automated techniques for base flow and recession analyses. Water Resources Research, 26(7), 1465-1473.

https://doi.org/10.1029/WR026i0 07p01465

Padilla, A., Pulido-Bosch, A., \& Mangin, A. (1994). Relative Importance of Baseflow and Quickflow from Hydrographs of Karst Spring. Ground Water, 32(2).

Palmer, A. N. (1999). Patterns of Dissolution Porosity in Carbonate Rocks. In Karst Waters Institute Special Publication 5. Karst Waters Institute, Inc.

Stevanović, Z. (2019). Karst waters in potable water supply: a global scale overview. Environmental Earth Sciences, 78(23), 1-12. https://doi.org/10.1007/s12665019-8670-9

Sudarmadji, Suprayogi, S., \& Setiadi. (2012). Konservasi Springs Berbasis Masyarakat di Kabupaten Gunungkidul. Universitas Gadjah Mada.

Surono, T. B., Sudarno, I., \& Wiryosujono, S. (1992). Geologi Lembar Surakarta-Giritontro, Jawa.

Sweeting, M. M. (1972). Karst Landforms. Micmilland.

Syahidin, U. (2016). Analisis Potensi Mata Air Karst untuk Kebutuhan Air Domestik Penduduk Desa Basuhan Kecamatan Eromoko Kabupaten Wonogiri. Universitas Muhammadiyah Surakarta.

Waltham, A. C., Smart, P. L., Friederich, H., Eavis, A. J., \& Atkinson, T. C. 
(1983). The Caves of Gunung Sewu. Cave Sci, 10, 55-96.

White, W B. (1993). Analysis of Karst Aquifer. Van Nostrand Reinhold.

White, William B. (2002). Karst hydrology: Recent developments and open questions. Engineering Geology, 65(2-3), 85-105. https://doi.org/10.1016/S00137952(01)00116-8
Wijayanti, P., Noviani, R., \& Tjahjono, G. A. (2015). Dampak Perubahan Iklim Terhadap Imbangan Air Secara Meteorologisdengan Menggunakan Metode Thornthwaite Mather Untuk Analisiskekritisan Air Di Karst Wonogiri. Geomedia: Majalah Ilmiah Dan Informasi Kegeografian, 13(1), 27-40. https://doi.org/10.21831/gm.v13i 1.4475 